\title{
Recognizing mid-career productivity: the 2008 Retrovirology Prize, call for nomination Kuan-Teh Jeang
}

Address: The National Institutes of Health, Bethesda, MD, USA

Email: Kuan-Teh Jeang - kjeang@niaid.nih.gov

Published: II September 2008

Retrovirology 2008, 5:80 doi:10.1186/1742-4690-5-80

This article is available from: http://www.retrovirology.com/content/5/l/80

(C) 2008 Jeang; licensee BioMed Central Ltd.

This is an Open Access article distributed under the terms of the Creative Commons Attribution License (http://creativecommons.org/licenses/by/2.0), which permits unrestricted use, distribution, and reproduction in any medium, provided the original work is properly cited.

Received: 7 September 2008

Accepted: II September 2008

\begin{abstract}
A recent analysis suggested a narrow age range for productivity of innovative work by researchers. The Retrovirology Prize seeks to recognize the research of a mid-career retrovirologist between the ages of 45 and 60. The 2007 Retrovirology Prize was awarded to Dr. Karen Beemon. Nominations are being solicited for the 2008 prize.
\end{abstract}

\section{Background}

In the August 18th, 2008, Wall Street Journal, George Anders wrote a column on the measures being taken by high technology companies in the United States to extend their researchers' age span of productivity. Anders cited an analysis performed by Benjamin Jones, a professor at Northwestern University's Kellogg School of Management, on innovative breakthroughs. Jones was reported to have examined the biographical data of more than 700 Nobel laureates and renowned researchers of the past century. One the conclusions reached by Jones was that "innovators are productive over a narrowing span (of approximately 25 years) of their life cycle" with researchers being most productive between the ages of just before 30 to 55 , peaking at age 40 . Reflecting the notion that innovative research often comes in early- to mid-career, Retrovirology seeks to recognize the work of a deserving retovirologist between the ages of 45 and 60 with the $M$. Jeang Retrovirology Prize [1].

Since its inception, the Retrovirology prize has been awarded three times, in 2005 to Stephen Goff [2], in 2006 to Joseph Sodroski [3], and in 2007 to Karen Beemon [4]. The Prize consists of an attractive crystal trophy (Figure 1), a $\$ 3,000$ cash award, and a profile article of the awardee published in Retrovirology. The Retrovirology Prize is supported, in part, through a donation from the Ming $\mathrm{K}$. Jeang Foundation, an educational foundation based in Houston, Texas, USA.

\section{Call for nominations and the selection process}

As stated previously [1], the Prize alternates yearly between recognizing a non-HIV retrovirologist (2007 and odd years) and an HIV retrovirologist (2008 and even years). There can be some discretion on this guideline, exercised from time-to-time by the selection committee. Any individual can initiate a nomination of others or selfnominate. A nomination includes a statement (1000 words or less) of the nominee's significant contributions to retrovirus research, a curriculum vitae of the nominee, and a statement by the nominator that the nominee has agreed to be nominated. The selection committee consists of the Editors of Retrovirology (currently, M. Benkirane, B. Berkhout, M. Fujii, K.T. Jeang, M. Lairmore, A. Lever, and M. Wainberg). All nominations submitted to the selection committee must be communicated through an Editorial Board member of Retrovirology. Hence, an individuals who is not an Editorial board member but who wishes to make a nomination should seek out a Retrovirology Editorial board member to communicate his/her information to 


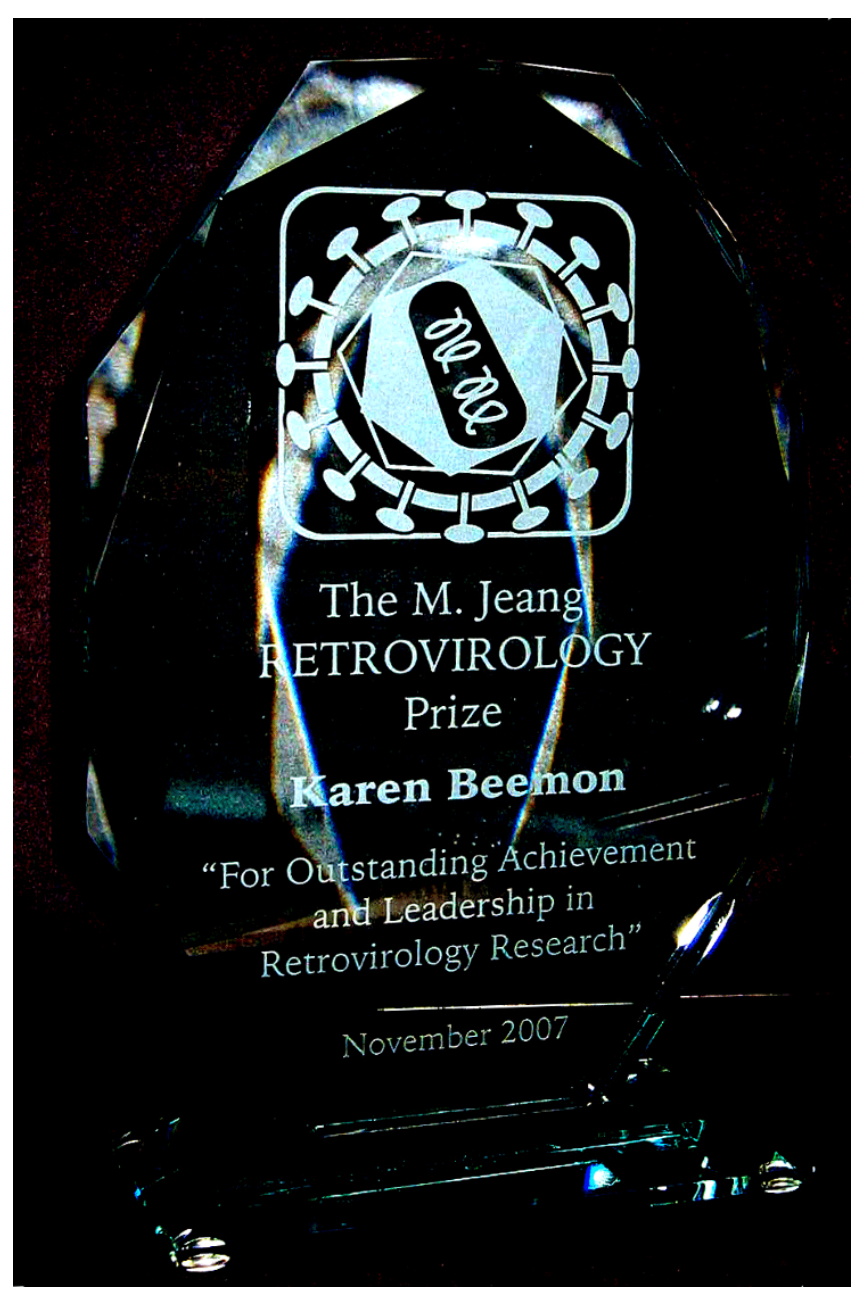

Figure I

A photograph of the crystal trophy presented to Dr. Karen Beemon, winner of the 2007 M. Jeang Retrovirology Prize.

the selection committee. A list of current Editorial Board members can be found at the Retrovirology website http:// www.retrovirology.com. Within the stipulated age limits, all Retrovirology Editors and Editorial Board members are eligible to be nominated with the exception of the Editorin-Chief who will administer the final selection.

For 2008, nominations will be accepted beginning on September $15^{\text {th }}$ and will close on October $30^{\text {th }}$. All members of the retrovirology community are encouraged to participate in this process for recognizing a deserving colleague.

\section{References}

I. Jeang K-T: The young, not-so-young, and the $\mathbf{2 0 0 7}$ Retrovirology Prize: call for nominations. Retrovirology 2007, 4:64.

2. Jeang K-T: Small philanthropy and big science: the RETROVIROLOGY prize and Stephen P. Goff. Retrovirology 2005, 2:43.

3. Lever AML: Science - A life fully lived: Joe Sodroski wins the 2006 Retrovirology Prize. Retrovirology 2006, 3:45.
4. Boris-Lawrie K: Bridging fundamental RNA biology, retroviral replication, and oncogenesis: Karen Beemon wins the 2007 Retrovirology Prize. Retrovirology 2007, 4:88.
Publish with BioMed Central and every scientist can read your work free of charge

"BioMed Central will be the most significant development for disseminating the results of biomedical research in our lifetime. "

Sir Paul Nurse, Cancer Research UK

Your research papers will be:

- available free of charge to the entire biomedical community

- peer reviewed and published immediately upon acceptance

- cited in PubMed and archived on PubMed Central

- yours - you keep the copyright
BioMedcentral 